\section{Awards in Anthropology}

The Wellcome Gold Medal for research in anthropology for 1936 has been awarded by the Council of the Royal Anthropological Institute to Dr. Charles Kingsley Meek for an essay entitled "Law and Authority in a Nigerian Tribe". In accordance with the terms of award laid down when the medal was instituted by the late Sir Henry Wellcome, the subject of research is the application of the science of anthropology to the problems of administration among backward peoples. Dr. Meek was formerly an officer of the Nigerian administrative service, and has for long been known as the foremost authority on the native tribes of Northern Nigeria. $\mathrm{He}$ is the author of a number of works in which the ethnography of the territory has received detailed treatment. The Council of the Institute has also awarded the Rivers Memorial Medal to Dr. Edward Evan EvansPritchard. This medal is awarded in recognition of recent meritorious field work. On this occasion, the Council has had before it the results of Dr. EvansPritchard's work in the Anglo-Egyptian Sudan and in Kenya since 1926. Dr. Evans-Pritchard, who was educated at Exeter College, Oxford, and studied anthropology at the London School of Economics, was appointed in 1926 by the Sudan Government to carry on the ethnographical survey of the tribes of the Anglo-Egyptian Sudan which had been initiated by Prof. C. G. Seligman, and later for a time was professor of anthropology in the University of Cairo. $\mathrm{He}$ has also acted as honorary secretary of the Royal Anthropological Institute. From time to time, the earlier results of his researches have been published in Sudan Notes and Queries and in the Journal of the Anthropological Institute. His further studies have appeared recently in a work on witchcraft among the Azande, which has been pronounced by those most competent to judge to be one of the outstanding works of recent years in anthropology. Dr. EvansPritchard is now engaged in preparing a further work on the religion and social organization of the Azande.

\section{Wool Research in Australia}

TrE decision of the Australian Government last year, at the instance of pastoralists, to impose a levy on wool production, has been followed by the appointment of a Wool Board, with six members representing the industry and one the Commonwealth Government. The levy may be up to $6 d$. per bale, and the funds are to be used for (i) scientific research and (ii) publicity for the benefit of all sides of the wool industry. The Board has recently determined upon its expenditure under the first heading during the next financial year, and its decisions should result in marked stimulation of scientific work, particularly of that being carried on under the auspices of the Council for Scientific and Industrial Research. $£ 2,750$ has been granted for extensions to the Council's Nutrition Laboratory in Adelaide ; $£ 1,600$ for sheep blowfly investigations at Canberra and Sydney; $£ 900$ for provision of additional accommodation at the McMaster Laboratory in Sydney; $£ 730$ per annum for three years for parasitological field work ; $£ 100$ capital and $£ 370$ per annum for three years for further study of external parasites of sheep; $£ 500$ for the Council's field station at St. Mary's, some twenty miles from Sydney; $£ 484$ for three years for increased staff for fertility studies; and minor amounts for further investigations into toxæmic jaundice, foot-rot and ophthalmia in sheep.

IN addition to these grants, the Australian Wool Board has agreed to support a project for establishing in South Queensland a field station for large-scale investigations of sheep problems, including tests of methods for mitigating the blowfly pest. The Queensland Government has granted the Commonwealth Council a thirty years lease, at a peppercorn rental, of an area of 40,000 acres in the Cunnamulla district. Towards the capital expenditure on buildings, fencing, etc., that will be necessary, the Board has allotted $£ 10,000$ in the first year and $£ 7,500$ in the second. The establishment of this station is cordially approved by wool-growers throughout Australia, and it should serve as an effective additional link between the practical growers and the research workers in the city laboratories.

\section{Arms for the British Association}

The British Association has received a grant of armorial bearings from the College of Arms, the necessary fees being met by gifts from an anonymous donor and from ex-presidents of the Association.

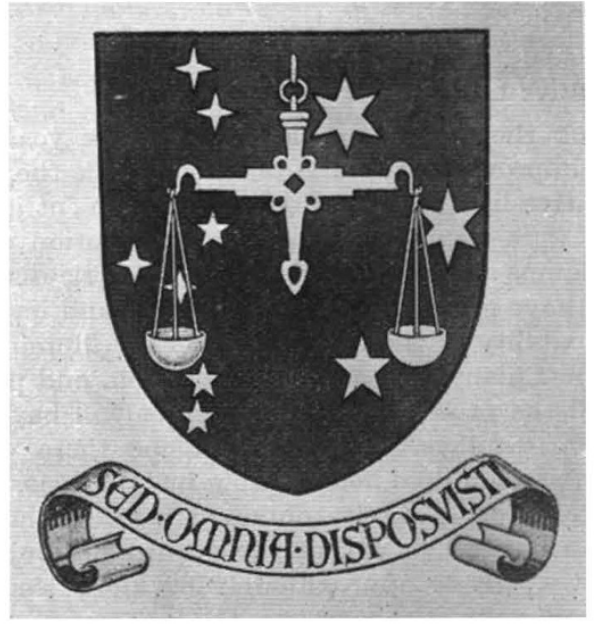

The shield is described as azure ten stars, two of six, four of five, and four of four points argent, representing the constellation of Libra; over all a balance or. The motto, Sed omnia disposuisti, is taken from "Wisdom of Solomon", ii, 20 (But Thou hast ordered all things in measure and number and weight).

\section{University of Sheffield and Sir Robert Hadfield}

In NATURE of October 10, 1936 (p. 610), reference was made to the appeal for $£ 250,000$ being made by the University of Sheffield for urgently needed extensions and for endowments. The first list of 
subscriptions was headed by a gift of $£ 10,000$ from Sir Robert Hadfield, to whom the University was already indebted for valuable donations and much support. It is now announced that Sir Robert has increased his donation to $£ 20,000$, this being the largest individual gift so far received in answer to the appeal. The announcement was made in the course of his address at the annual meeting last month of Messrs. Hadfields, Ltd., and Sir Robert added that he was moved to add to his original donation by the noteworthy address delivered early last March by General Smuts on "The University in Civic Training", when he was installed as Chancellor of the University of Cape Town. General Smuts believes that the university is the hope of civilization, the one place where fact is exalted above sectional loyalties and ideologies. Sir Robert has given substantial proofs that he, likewise, has faith in the university as an institution of vital significance for the future of humanity. It is to be hoped that his great benefactions to the University of Sheffield will stimulate other industrialists to play their part in supporting more liberally, if not universities in general, at least the particular university to which they must look for development and progress in their own field. Sir Robert Hadfield, it may be noted, celebrated the fiftieth anniversary of his election to the Institution of Civil Engineers on March 1, when he received a congratulatory address from the president, and on March 23 was elected an honorary member of the Institution, for his "long and conspicuous service in the advancement of metallurgical science".

\section{Decorative Lighting for the Coronation}

SINCE the last coronation, twenty-six years ago, great improvements have taken place in the art of decorative lighting. In 1911, metal filament and arc lamps were used. Since then the invention of gasfilled lamps and the development of electric-discharge lamps have greatly cheapened the cost and improved the flexibility of the illumination. The illuminations will show many new aspects of London, and practically all the principal provincial cities will have very effective displays. In London alone there will be nearly two hundred floodlighting installations, and in the provinces, statistics obtained from six hundred local authorities show that the mean additional load per town will be approximately 60 kilowatts. This does not take into account the numerous smaller schemes of strip-lighting and illuminated devices with which shops and business premises will be decorated. For the first time, the fountains in Trafalgar Square are being illuminated by means of eight submersible reflectors taking 500-watt gas-filled lamps. In addition to all four sides of 'Big Ben', the terrace of the Houses of Parliament is being flood. lighted for the first time. Two novelties are, $30-\mathrm{ft}$. high electric 'bonfires' with flame effects on the roof of the Shell Mex House, and colour changing equipment for illuminating $30-\mathrm{ft}$. high jets of water from fire floats stationed outside the new London Fire Brigade headquarters. A very large sodium flood- lighting installation used at Dunfermline Abbey and Edinburgh Castle give an outstanding and beautiful display of decorative lighting.

\section{The German Airship Disaster}

THE latest and largest German airship, Hindenburg, was destroyed by fire while landing at Lakehurst, New Jersey, U.S.A., on the evening of May 6. This was the terminal point of her first voyage of the year from Frankfort-on-Main. She carried 39 passengers and 61 crew, approximately half of whom were killed or afterwards died of injuries. The airship had been cruising about for an hour during a heavy storm, which was judged to be too severe for safe landing, and was just coming in at about 300 feet above the ground, dropping her nose mooring lines for the landing crew on the flying field. Reports state that a burst of flame was seen at the stern. In a few moments the whole ship was enveloped in fire. This was evidently due to the ignition of the hydrogen in the gas bags, as the report mentions the exceptional brilliance of the fire. No details are yet avail. able upon which any useful theories as to the cause of the fire can be based, but the fact that the ship had been cruising around the field in a heavy thunderstorm lends colour to the suggestion that she was electrically charged, and raises the possibility of sparks having occurred when the landing ropes earthed her. It is known that special precautions against this were embodied in her design, and therefore this theory assumes some additional accident. Whatever was the original cause of the accident, it is certain, as was the case with the British airship $R$ 101, that the ignition of the highly inflammable hydrogen was responsible for the completeness of the disaster.

\section{The Electrical Industry of the World}

THE twenty-ninth report of the Imperial Economic Committee (London : H.M. Stationery Office. $2 s .6 d$. net) gives a survey of the trade in electrical machinery and apparatus. The latest information given relates to the year 1935. Perhaps the most significant feature during the last five years is the leading part that radio receiving sets have been occupying. At the end of 1935 there were 56 million sets of this type of apparatus in use, the increase having nearly doubled in five years. There were 22.5 million sets installed in the United States, and this works out to 178 per 1,000 of the population. The consumption of electrical energy used in radio receiving was 1,540 million kilowatt hours per annum. The corresponding figures for Great Britain, which was second in the world's list, was 7.4 million sets, and the third was Germany with $7 \cdot 2$ million. On the other hand, the increase in the world's telephones was comparatively small. This is ascribed primarily to an actual decrease in the United States and Canada. But these two countries still lead in this form of communication. It is worthy of note that there is a greater number of telephones per head of population in agricultural countries like Denmark, New Zealand and Australia, than there is in industrial 